\title{
Modeling the spatial distribution of a tropical dry forest tree facing climate change
}

\author{
Fernanda Moura Fonseca Lucas $^{1 *} \oplus$, Kyvia Pontes Teixeira das Chagas $^{1} \oplus$, Fábio de Almeida Vieira² $₫$ \\ ${ }^{1}$ Universidade Federal do Paraná, Curitiba, PR, Brasil. E-mail: fernanda-fonseca@hotmail.com; kyviapontes@gmail.com \\ ${ }^{2}$ Universidade Federal do Rio Grande do Norte, Macaíba, RN, Brasil. E-mail: vieirafa@gmail.com
}

ABSTRACT: Species distribution models have become an essential tool for the selection of conservation areas. Given this perspective, this research aimed to analyze the dynamics of the fundamental niche of Ziziphus joazeiro Mart. facing climate change. The MaxEnt algorithm was used to correlate species points of occurrence with bioclimatic variables of four periods: Middle Holocene, current period, and the optimistic and pessimistic future scenarios of the HadGEM2-ES model of general atmospheric circulation. The accuracy of the predictions and the influence of the variables was evaluated using the area under the curve (AUC index) and the Jackknife test. The predictions showed high precision (AUC >0.895), and the bioclimatic variables related to precipitation were the ones that most contributed to determining potential areas for the occurrence of the species. A reduction of more than $60 \%$ was observed in the area with climatic suitability for the occurrence of $Z$. joazeiro, over time. The range that comprises the central region of the distribution of the species stands out as the region with the greatest suitability, as projected for the current and future period, this being the area that should receive the most attention for the conservation programs of the species.

Key words: biogeography; climatic variables; juazeiro; Rhamnaceae

\section{Modelagem de distribuição espacial de uma espécie arbórea de uma floresta tropical seca frente a mudança climática}

RESUMO: Os modelos de distribuição das espécies tornaram-se uma ferramenta essencial para a seleção de áreas de conservação. Dada esta perspectiva, esta pesquisa teve como objetivo analisar a dinâmica do nicho fundamental do Ziziphus joazeiro Mart. frente a mudança climática. $\mathrm{O}$ algoritmo MaxEnt foi usado para correlacionar pontos de ocorrência das espécies com variáveis bioclimáticas de quatro períodos: Holoceno médio, período atual e os cenários futuros otimista e pessimista do modelo HadGEM2-ES de circulação geral atmosférica. A precisão das predições e a influência das variáveis foi avaliada usando a área sob a curva (índice AUC) e o teste de Jackknife. As predições mostraram alta precisão $(A U C>0,895)$ e as variáveis bioclimáticas relacionadas à precipitação foram as que mais contribuíram para determinar áreas potenciais para a ocorrência da espécie. Foi observada uma redução de mais de $60 \%$ na área com adequabiliade climática para a ocorrência de Z. joazeiro, ao longo do tempo. A faixa que compreende a região central da distribuição da espécie se destaca como a região com maior adequação, conforme projetada para o período atual e futuro, sendo esta a área que deve receber mais atenção para os programas de conservação da espécie.

Palavras-chave: biogeografia; variáveis climáticas; juazeiro; Rhamnaceae

\footnotetext{
* Fernanda Moura Fonseca Lucas - E-mail: fernanda-fonseca@hotmail.com (Corresponding author)

Associate Editor: Rinaldo Luiz Caraciolo Ferreira
} 


\section{Introduction}

The species' niche is the joint description of the environmental conditions that allow the species to meet minimum requirements for occurrence on a temporal and spatial scale. In this case, the birth rate of a local population will be equal to or greater than the mortality rate, together with the impacts associated with environmental conditions on the population (Soberón \& Peterson, 2020). The understanding of the niche dynamics contributes to the clarification of how the species is maintained over a long time, being possible to relate to climatic changes and their evolutionary histories (Vieira et al., 2015).

In this sense, ecological niche modeling (ENM) is a study that performs the correlation between the geographical occurrence of a species and a set of environmental variables, to predict the mechanisms that govern its spatial distributions (Yang et al., 2020). In recent years, ENM has become an increasingly important tool to address various issues in ecology, such as conservation practices, indicating regions with suitability for the occurrence of the species evaluated (Costa et al., 2018; Chagas et al., 2020).

These studies contribute to the investigation of priority areas for conservation, since they show the locations potentially suitable for a given species in protected areas, allowing their maintenance, avoiding the loss of genetic diversity and its ecosystem services (Costa et al., 2018; Chagas et al., 2020). This approach allows us to subsidize decisionmaking in programs for the recovery of degraded areas, since the species chosen for the program may have niche limitations in certain regions (Greiser et al., 2020). Based on this study, it is also possible to understand the restrictions on species distributions in other biomes or ecosystems.

Tropical Dry Forests (TDFs), comprise a formation found within a vegetation type complex being considered a global metacommunity, which is found in Brazil, mainly in the Northeast region represented by the Caatinga biome (Pennington et al., 2009). However, TDFs are being drastically affected worldwide due to factors such as the expansion of agribusiness, climate change, and forest fires; these changes radically affect the species present, making it necessary to know about their distributions (Silva et al., 2018). Another problem that threatens TDFs is desertification. Due to the dry climate and land-use practices without proper management, ecosystem losses in TDFs due to desertification can be further aggravated with climate change (Costa et al., 2016a).

Face the vulnerability present in this region and in the case of vegetation losses that may happen, studies that assist in species conservation strategies are essential. Given this perspective, the work aimed to analyze the potential geographic distribution of Ziziphus joazeiro Mart., a native species of the Caatinga biome. Specifically, we sought to understand the dynamics of the species in the face of current climatic changes, from the Holocene to future scenarios. We hypothesize that: i) the Holocene period represents the maximum suitability of the species; ii) the temperature increase in future conditions will alter the areas of greatest suitability of the species in the Caatinga biome; iii) suitability will be preserved in transition areas with the Atlantic Forest biome where the species occurs most frequently.

\section{Materials and Methods}

\section{Target species}

The Ziziphus joazeiro Mart. (Rhamnaceae), popularly known as juazeiro, is one of the symbol plants of the Caatinga biome and has relevant cultural interest (Maia, 2004). The species has several uses, offering promising natural resources for the development of antibiotics, also, its non-acidic fruits are sources of fiber (Oliveira et al., 2020). Its wood is used for various uses such as rural buildings and carpentry; also, it contains a high content of cellulose and lignin. It can be used for the production of ethanol, besides presenting high ecological relevance, as a food source for fauna (Maia, 2004).

\section{Data acquisition}

The predictive modeling carried out in this research analyzed the fundamental ecological niche, which consists of the abiotic conditions set that determine the occurrence of the species without taking into account biotic limitations such as competition and predation (Soberón \& Peterson, 2020). The occurrence points of the Ziziphus joazeiro were obtained from the database available on the speciesLink website (http:// splink.cria.org.br). These went through a filtering process, where duplicate coordinates, discrepant locations, and cultivar descriptions were eliminated. Also, there was filtering so that the occurrences had a minimum distance radius of 5 $\mathrm{km}$, avoiding overlap (Oliveira et al., 2018). It was obtained one hundred ninety-six points of the natural occurrence of the species (Figure 1).

Scenarios with bioclimatic variables for the current period (average from the 1960s to the 1990s) and future projection, 2070 (average from 2061 to the 2080s) were used in the modeling. A set of 19 bioclimatic variables (Table 1) was obtained from the WorldClim version 1.4 database available on the www.worldclim.org website, with a spatial resolution of 30 arc-seconds ( $1 \mathrm{~km}$ ). The variables were obtained from the Northeast of Brazil to the state of Minas Gerais, which in its Northern portion, presents the Caatinga biome. These variables are derived from the monthly values of temperature and precipitation, representing annual trends, seasonality, and extreme limiting factors.

For a future projection (2070), we used the HadGEM2ES global climate model and two scenarios from the IPCC (2007). The RCP 8.5 considered pessimistic, with high levels of energy demand and greenhouse gases, resulting in radioactive radiation of $8.5 \mathrm{Wm}^{-2}$ until the year 2100 and RCP 2.6 considered optimistic, presenting a lower evolution of $\mathrm{CO}_{2}$ concentration over the century (Deb et al., 2017). The same model was used for a project referring to the past, related to the middle Holocene (about 6000 years ago). 


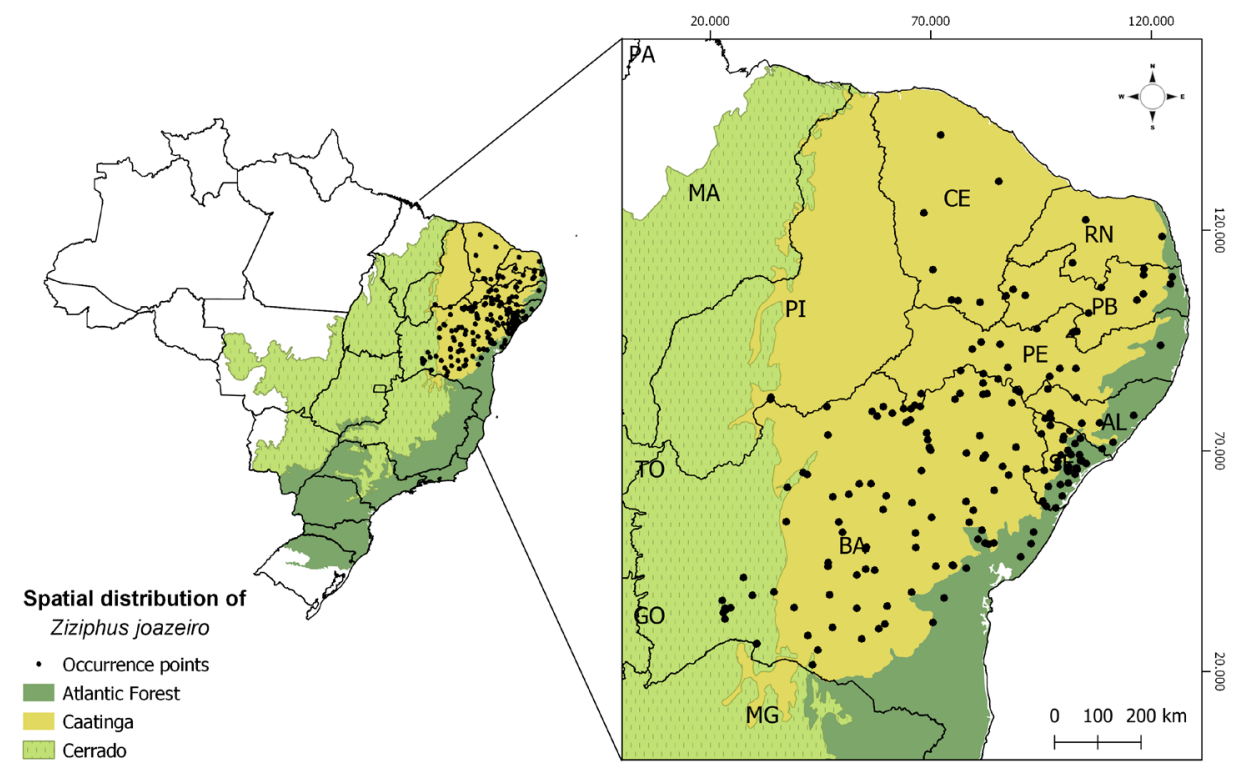

Figure 1. Points of occurrence of the Ziziphus joazeiro Mart. and its geographical distribution across Brazilian states.

All available environmental variables were subjected to multicollinearity analysis using Pearson's correlation, using the ENMTools version 1.4.3 program (www.enmtools. blogspot.com). They were excluded from the set of variables highly correlated for the study region $(r \geq 0.85$ or $r \leq-0.85)$, reducing the chance of overfitting, as the collinearity between two variables makes it difficult to estimate the parameters accurately (Wei et al., 2017).

Table 1. Description of the 19 bioclimatic variables used in modeling the ecological niche of the species.

\begin{tabular}{cl}
\hline $\begin{array}{c}\text { Bioclimatic } \\
\text { variables }\end{array}$ & \multicolumn{1}{c}{ Description } \\
\hline Bio 1 & Annual average temperature \\
Bio 2 & Average daytime temperature variation \\
Bio 3 & Isothermality \\
Bio 4 & Temperature seasonality \\
Bio 5 & Max. Temperature of the hottest month \\
Bio 6 & Min. Temperature of the coldest month \\
Bio 7 & Current thermal amplitude \\
Bio 8 & Average temperature of the wettest trimester \\
Bio 9 & Average temperature of the driest trimester \\
Bio 10 & Average temperature of the hottest trimester \\
Bio 11 & Average temperature of the coldest trimester \\
Bio 12 & Annual rainfall \\
\hline Bio 13 & Rainiest month precipitation \\
Bio 14 & Precipitation of the driest month \\
\hline Bio 15 & Precipitation seasonality \\
\hline Bio 16 & Rainier quarter rainfall \\
Bio 17 & Precipitation of the driest trimester \\
Bio 18 & Precipitation in the hottest trimester \\
\hline Bio 19 & Precipitation of the coldest trimester \\
\hline
\end{tabular}

\section{Data processing}

The maximum entropy algorithm was used in the Maxent software version 3.3.3k (Phillips et al., 2006). Maxent estimates the distribution of the species under study using real occurrence data and combinations with climatic variables. This algorithm demonstrated better results when compared to other methods (Elith et al., 2006). According to Li et al. (2020), Maxent reports response curves for each combination to the environmental variable and estimates the importance of each in the species distribution.

The parameters used in the model were a convergence threshold of $1.0 \mathrm{E}-5$ with 5,000 interactions. The contribution of each climatic variable was analyzed using Jackknife and AUC (area under the curve) methods. The data set was subjected to 10 replications of the model, and for each one, cross-validation was performed. Both the calculation of the AUC index and the Jackknife statistical test calculated using the post-analysis tools available in the Maxent software.

\section{Analysis and interpretation}

The area under the curve is taken as a measure of the model's accuracy (Phillips et al., 2006). According Swets (1988), the results obtained in the AUC can be interpreted according to intervals: $(0.5-0.7)$ poor discrimination capacity; $(0.7-0.9)$ reasonable discrimination ability; and $(0.9-1.0)$ very good discrimination.

The models generated by Maxent were analyzed using the Qgis 2.18 software (www.qgis.org). Each pixel varies from 0-1 for the environmental suitability of the species, being represented on the map by gradients of five class, in which: very high suitability (red), high, medium, low, and very low

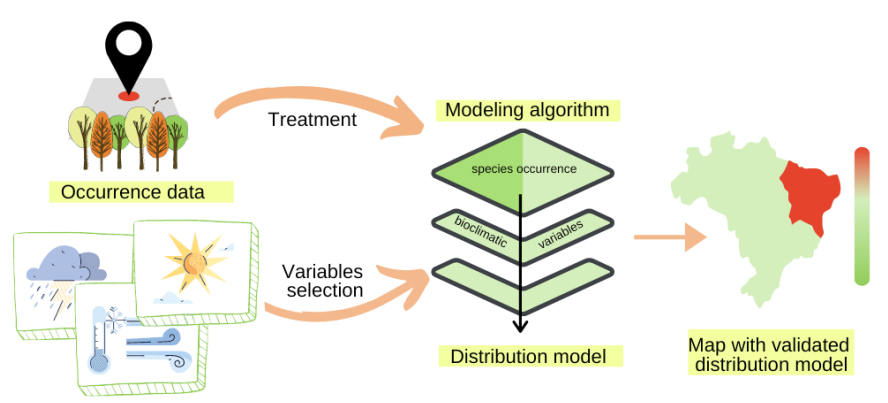

Bioclimatic variables

Figure 2. Flowchart summary of data processing steps. 
(green). Thus, the past, present, and future periods were compared and their areas were estimated.

\section{Results and Discussion}

The $Z$. joazeiro was found to be distributed in almost all the states of Northeastern Brazil (Figure 1). According to the literature, $Z$. joazeiro is an endemic species in the Caatinga (Maia, 2004; Oliveira et al., 2020). However, the results obtained in this study indicate that the species has a constant occurrence in the areas of biome transitions and also on the coast, which can characterize it as native to the Caatinga, but not endemic. This occurrence of $Z$. joazeiro in the coastal region can be explained by the great capacity that some species of the Caatinga must adapt to disturbed environments (with vegetation removed), thus being able to call them "ruderal". According to Costa et al. (2016b), the species has a high potential to develop in different environments, adapting well to soils with different textures and chemical compositions. Thus, the abundance of $Z$. joazeiro in the transition areas may have allowed the species to use this plasticity to colonize new areas, especially in environments with no competition from Atlantic Forest species.

Through multicollinearity analysis, 11 variables were selected for the modeling (Table 2). Jackknife test provided the percentage of gain that each variable brings to the model and result of the revaluation of the model at each permutation (between the variables and consequent drop in accuracy levels). The annual precipitation (bio 12) showed greater importance of permutation (\% IP) for the current period. In contrast, the precipitation of the hottest quarter (bio18) stood out for the Holocene and the prediction of the pessimistic future. For the optimistic future scenario, the minimum temperature of the coldest month (bio 06) showed the highest IP (Table 2).

The variable that presented the most significant relative contribution to the Holocene, as well as to the pessimistic future scenario, was the precipitation of the wettest month (bio 13). In contrast, for the present and the optimistic future, annual precipitation (bio 12) is considered.

In all simulations, the variables related to rain conditions were the most important for determining the areas with potential suitability of the species, indicating that the $Z$. joazeiro is more sensitive to this variable. According to Chagas et al. (2020), this is an expected response since the presence of rain is a limiting factor of the vegetation occurrence in Caatinga. Also, the same authors found a similar result for jurema-preta (another native species of the biome), where the annual precipitation was the variable with the most significant influence to predict its occurrence.

The HadGEM2-ES model presented an adequate performance in all scenarios for the representation of the target species (AUC> 0.895), considering that the closer to 1 the index value, the more distant it will be from the random forecast (Phillips et al., 2006). It is clear that a reduction in the area with greater climatic suitability, starting from the Holocene to future scenarios (Figure 3 ). Adding the areas of high and very high climatic suitability for $Z$. joazeiro, the Holocene obtained 42.904 .621 ha, which was reduced by $28 \%$ for the current period and by more than $60 \%$ for future scenarios.

Similar results of habitat loss were found for other tree species around the world, such as Juniperus procera, an endangered tree species from Ethiopia, where suitable habitats will be decreased by more than $70 \%$ at the end of the century (Abrha et al., 2018). Buras \& Menzel (2019), reports a future reduction (2061-2090) of more than 70\% suitable habitats of the 26 most abundant forest species in Europe, considering an optimistic and pessimistic scenario. It is important to note that the result of the modeling indicates whether a site is satisfactory to the species and not precisely if it is being occupied by it.

According to normal climate conditions, during the middle Holocene, the Northeast of Brazil had a wetter and colder climate than the current one. This explains the large suitability

Table 2. Percentage values of contribution (\% C) and importance of permutation (\% IP) of the environmental variables for the Holocene, currently, optimistic future (RCP 2.6), and pessimistic (RCP 8.5).

\begin{tabular}{ccccccccc}
\hline \multirow{2}{*}{$\begin{array}{c}\text { Variables/ } \\
\text { Periods }\end{array}$} & \multicolumn{2}{c}{\begin{tabular}{c} 
Current \\
\cline { 3 - 10 }
\end{tabular}} & & \multicolumn{2}{c}{ Holocene } & \multicolumn{2}{c}{$\begin{array}{c}\text { Future } \\
\text { RCP 2.6 }\end{array}$} & \multicolumn{2}{c}{$\begin{array}{c}\text { Future } \\
\text { RCP 8.5 }\end{array}$} \\
\cline { 2 - 10 } & \%C & \%IP & \% C & \% IP & \% C & \% IP & \% C & \% IP \\
\hline Bio 02 & 13 & 2.7 & 2.3 & 2.5 & 5.3 & 1.2 & 3.5 & 2 \\
Bio 03 & 3.3 & 5 & 5.9 & 6 & 2.1 & 1.6 & 1.9 & 5.6 \\
Bio 05 & 3.2 & 2.5 & 8.5 & 11.6 & 3.5 & 13.2 & 12.7 & 15.9 \\
Bio 06 & 0.9 & 5.1 & 1.8 & 15.8 & 4 & 31.9 & 1.9 & 7.9 \\
Bio 07 & 8.9 & 6.8 & 6.8 & 7.4 & 24.8 & 11.6 & 3.4 & 3.7 \\
Bio 08 & 0.7 & 0.6 & 0.4 & 2.8 & 0.5 & 1.5 & 3.1 & 2.5 \\
Bio 12 & 55.2 & 64.6 & 4 & 15.8 & 49.4 & 11.8 & 9.6 & 10.7 \\
Bio 13 & 1.2 & 0.6 & 55 & 3.2 & 1.2 & 4.4 & 50.6 & 7.2 \\
Bio 14 & 1.5 & 7.3 & 1.6 & 8.8 & 1.9 & 13.5 & 1.7 & 6.1 \\
Bio 18 & 6 & 1.6 & 11.8 & 19.7 & 5.2 & 8.2 & 7.4 & 21.5 \\
Bio 19 & 6 & 3.3 & 2 & 6.5 & 2 & 1.1 & 4.1 & 16.8 \\
AUC & $0.947 \pm 0.005$ & $0.895 \pm 0.019$ & & $0.969 \pm 0.005$ & $0.907 \pm 0.019$ \\
\hline
\end{tabular}




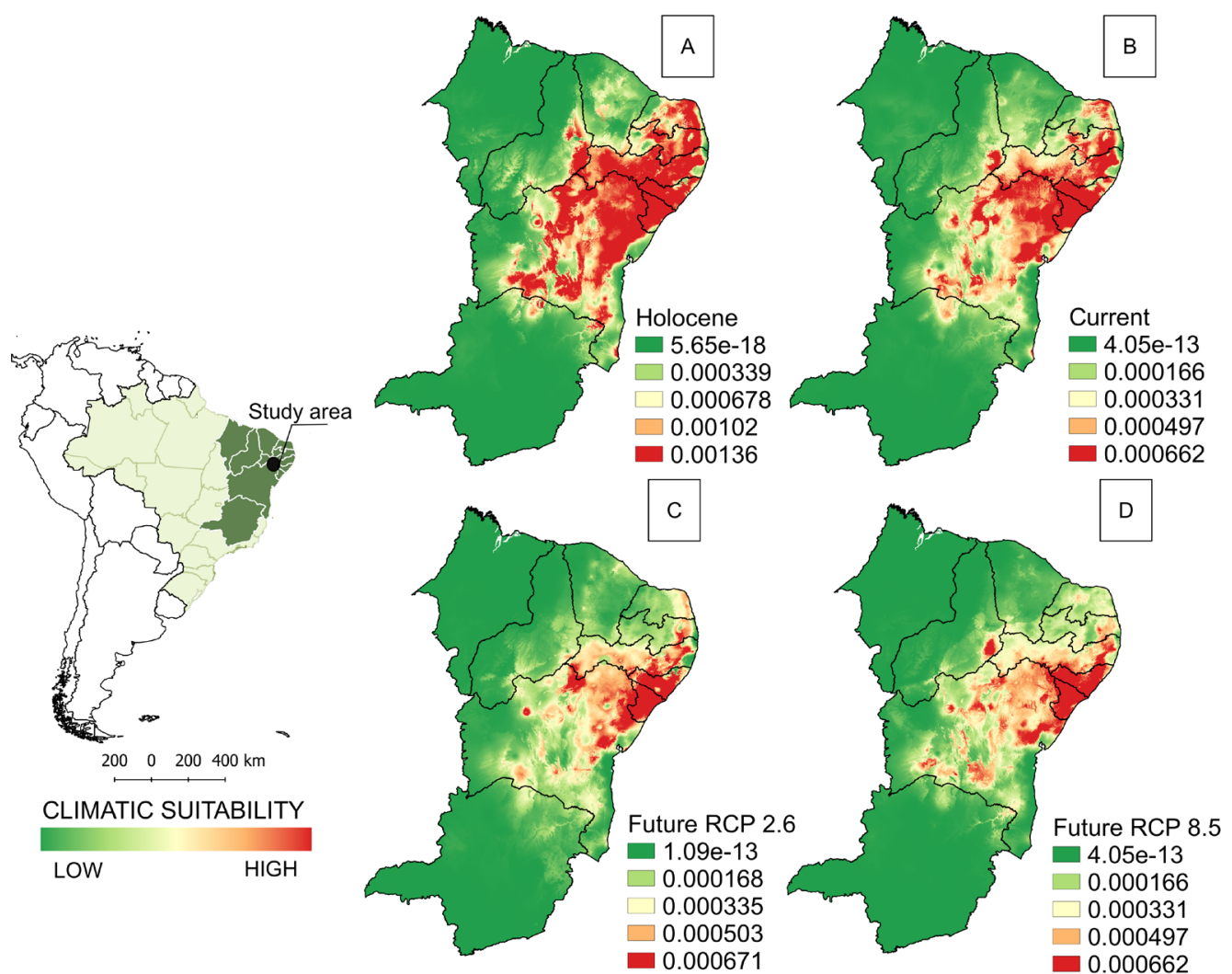

Figure 3. Maps of potential distribution for the Holocene (A), current period (B), and the future: optimistic RCP 2.6 (C) and pessimistic RCP 8.5 (D) of the Ziziphus joazeiro Mart. with a scale of climatic suitability of the species.

area of the species in the past. Besides, studies report that during this period, the typical vegetation was Savana instead of Caatinga (Melo \& Marengo, 2008). The future scenarios showed areas with more significant potential of occurrence near the coast, concentrating mainly on a coastal strip between the states of Pernambuco and Bahia.

Although no occurrence records were obtained in the database for the state of Minas Gerais, in its Northern portion where the Caatinga biome is located, there was a high climatic aptitude for the occurrence of $Z$. joazeiro in the current period and an average aptitude for future scenarios. The state of Paraíba, which was highly apt for the occurrence of the species in the current projection, showed a significant reduction in future scenarios. A similar situation observed in the state of Rio Grande do Norte, which previously had some fragments with high climatic suitability, mainly in the region that comprises the Agreste, in future scenarios, it has become a region with suitability ranging from average to low.

In a study on the niche modeling of five species of cacti endemic to the Caatinga, there was a retraction of areas of environmental suitability and a great risk of extinction due to climate change for the future scenario (Simões et al., 2019). Reinforcing the need for regional conservation actions to guarantee the survival of endemic species. Sobrinho et al. (2019) highlight the vulnerability of the biome and the importance of impact prediction studies in future scenarios, to assist in directing research and preventive measures.
Future climate projections point out that at the end of the 21st century, the Caatinga and the Northeast portion of the Atlantic Forest will face conditions of intense warming with an increase from 3 to $4.5^{\circ} \mathrm{C}$ in temperature, as well as a severe decrease in precipitation, between 30 and 50\% (PBMC, 2013). As a result, it may drastically affect the area of occurrence of the $Z$. joazeiro in this biome, as the semi-arid vegetation will tend to be replaced by arid-land vegetation (Salazar et al., 2007; IPCC, 2007). According to Silva et al. (2019), these changes can compromise the ecological dynamics of plants and animals in the Caatinga, negatively impacting biotic interactions, such as pollination and seed dispersal, where the specialized species will be the most affected (Silva et al., 2019). Ceballos et al. (2009) report that climate change will substantially disturb the forests of the Neotropical region.

The prediction addressed in this study indicates areas with potential of suitability for the occurrence of the species in future scenarios, contributing to the definition of priority areas for conservation. Also, the distribution shown in the current period can be a subsidy for reforestation programs. Based on the results, it is recommended to encourage conservation programs for the $Z$. joazeiro in the protected areas that lie between the Agreste and the Zona da Mata that connects the South region of Pernambuco state to the North of Bahia state, mainly on the coast of Alagoas and Sergipe states. This area proved to be a central area of environmental suitability for $Z$. joazeiro through the current and future scenarios. 


\section{Conclusion}

The models were obtained with high accuracy, and the bioclimatic variables related to precipitation were the ones that most contributed to the prediction.

Based on the comparative projection between the Holocene, the current distribution, and the predictions for the future, the area of climatic suitability for the occurrence of $Z$. joazeiro showed a reduction higher than $60 \%$ in future scenarios.

Future climate changes may provide an increase in temperature and a reduction in the rainfall rate for the region comprising the Caatinga, negatively affecting the species' niche.

The range comprising the states of Sergipe and Alagoas stands out as the region that presents the highest climatic suitability according to the projection for the current period and future scenarios, this is the area that should receive the most attention for conservation programs of the $Z$. joazeiro.

Other factors, in addition to bioclimatic ones, should be considered for modeling studies whenever available, thus, providing for to more accurately the potential areas of suitability and the possible justifications for their expansion or retraction.

\section{Acknowledgments}

The present work was financed in part by the Conselho Nacional de Desenvolvimento Científico e Tecnológico - CNPq (PIBIC scholarships) and the Coordenação de Aperfeiçoamento de Pessoal de Nível Superior - Brazil (CAPES) - Finance Code 001.

\section{Compliance with Ethical Standards}

Funding: Conselho Nacional de Desenvolvimento Científico e Tecnológico (CNPq), Coordenação de Aperfeiçoamento de Pessoal de Nível Superior - Brasil (CAPES) - Finance Code 001.

Conflict of interest: All authors declare they have no conflict of interest competing financially or professionally that may influence the article.

Author contribution: Conceptualization: FMFL; Data curation: FMFL; Formal analysis: FMFL, KPTC, FAV; Funding acquisition: FAV; Investigation: FMFL, KPTC; Methodology: FMFL, KPTC, FAV; Project administration: FMFL, FAV; Resources: FAV; Software: FMFL, KPTC; Supervision: FAV; Validation: KPTC, FAV; Visualization: FMFL; Writing - original draft: FMFL; Writing - review \& editing: FMFL, KPTC, FAV.

\section{Literature Cited}

Abrha, H.; Birhane, E.; Hagos, H.; Manaye, A. Predicting suitable habitats of endangered Juniperus procera tree under climate change in northern Ethiopia. Journal of Sustainable Forestry, v.37, n.8, p.842-853, 2018. https://doi.org/10.1080/10549811. 2018.1494000 .
Buras, A.; Menzel, A. Projecting tree species composition changes of European forests for 2061-2090 under RCP 4.5 and RCP 8.5 scenarios. Frontiers in Plant Science, v. 9, e1986, 2019. https:// doi.org/10.3389/fpls.2018.01986.

Ceballos, G.; Vale, M. M.; Bonacic, C.; Calvo, J.; List, R.; Bynum, N.; Medellín, R. A.; Simonetti, J. A.; Rodríguez, J. P. Conservation Challenges for the Austral and Neotropical America Section. Conservation Biology, v. 23, n.4, p.811-817, 2009. https://doi. org/10.1111/j.1523-1739.2009.01286.x.

Chagas, K. P. T.; Lucas, F.M. F.; Vieira, F. A. Predictive modeling of Mimosa tenuiflora (Willd.) Poiret: How can climate change affect its potential distribution range? Revista Floresta, v. 50, n.2, 13151324, 2020. https://doi.org/10.5380/rf.v50i2.62980.

Costa, A. R. S.; Ferreira, G. L. F.; Souza, E. B. Rolim Neto, F. C. Desertification in semi-arid northeast of Brazil. Revista Geama, v. 2, n.4, p.427-445, 2016a. http://www.journals.ufrpe.br/index. php/geama/article/view/920/1387. 22 Jun. 2020.

Costa, J. D. S.; Silva, J. A. B.; Coelho, D. S.; Santos, I. E. A.; Seabra, T. X. Methods for overcoming seed dormancy and the initial growth of Ziziphus joazeiro Mart. in different soils. Revista Caatinga, v. 29 , n. 2, p.441-449, 2016b. https://doi.org/10.1590/198321252016v29n221rc.

Costa, T. R.; Moura, C. C.; Machado, E. L. M; Bueno, M. L. Modelagem preditiva da espécie Lychnophora pohlii Sch. Bip., no estado de Minas Gerais. Revista Nativa, v.6, n.1, p.100-106, 2018. https:// doi.org/10.31413/nativa.v6i1.4696.

Deb, J. C.; Phinn, S.; Butt, N.; McAlpine, C. V. The impact of climate change on the distribution of two threatened Dipterocarp trees. Ecology and Evolution, v. 7, n.7, p.2238-2248, 2017. https://doi.org/10.1002/ece3.2846.

Elith, J.; Graham, C. H.; Anderson, R. P.; Dudi'K, M.; Ferrier, S.; Guisan, A.; Hijmans, R. J.; Huettmann, F.; Leathwick, J.R.; Lehmann, A.; Li, J.; Lohmann, L. G.; Loiselle, B. A.; Manion, G.; Moritz, C.; Nakamura, M.; Nakazawa, Y., Overton, J.Mcc.; Peterson, A. T.; Phillips, S. J.; Richardson, K. S.; Scachetti-Pereira, R.; Schapire, R. E.; Sobero'N, J.; Williams, S.; Wisz, M. S; Zimmermann, N. E. Novel methods improve prediction of species' distributions from occurrence data. Ecography, v.29, n.2, p.129-151, 2006. https:// doi.org/10.1111/j.2006.0906-7590.04596.x.

Greiser, C.; Hylander, K.; Meineri, E.; Luoto, M.; Ehrlén, J. Climate limitation at the cold edge: contrasting perspectives from species distribution modelling and a transplant experiment. Ecography, v.43, n.5, p.637-647, 2020. https://doi.org/10.1111/ecog.04490.

Intergovernmental Panel on Climate Change - IPCC. Climate Change 2007 - Impacts, Adaptation and Vulnerability. Contribution of Working Group II to the Fourth Assessment Report of the Intergovernmental Panel on Climate Change. Cambridge: Cambridge University Press, 2007. 976p. https://www.ipcc.ch/site/assets/uploads/2018/03/ ar4_wg2_full_report.pdf. 22 Jun. 2020.

Li, Y.; Li, M.; Li. C.; Liu Z. Optimized Maxent model predictions of climate change impacts on the suitable distribution of Cunninghamia lanceolata in China. Forests, v. 11, n. 3, e302, 2020. https://doi.org/10.3390/f11030302,

Maia, G. N. Caatinga: árvores e arbustos e suas utilidades. São Paulo: D \& Z Computação Gráfica e Editora, 2004. 413p. 
Melo, M. L. D.; Marengo, J. A. Simulações do clima do holoceno médio na América do Sul com modelo de circulação geral da atmosfera do CPTEC. Revista Brasileira de Meteorologia, v. 23, n. 2, p. 191205, 2008. https://doi.org/10.1590/S0102-77862008000200007.

Oliveira, B. F.; Costa, G. C.; Fonseca, C. R. Niche dynamics of two cryptic Prosopis invading South American drylands. Biological Invasions, v. 20, n.1, p. 181-194, 2018. https://doi.org/10.1007/ s10530-017-1525-y.

Oliveira, P. M. L.; Dantas, A. M.; Morais, A. R. S.; Gibbert, L.; Kruger, C. C. H.; Lima, M. S.; Magnani, M.; Borges, G. S. C. Juá fruti (Ziziphus joazeiro) from Caatinga: A sourcce o dietary fiber and bioaccessible flavonols. Food Reasearch International, v.129, e108745, 2020. https://doi.org/10.1016/j.foodres.2019.108745.

Painel Brasileiro de Mudanças Climáticas - PBMC. Contribuição do Grupo de Trabalho 1 ao primeiro relatório de avaliação nacional do Painel Brasileiro de Mudanças Climáticas. Sumário executivo GT1. Rio de Janeiro: PBMC, 2013. 24p. http://www.pbmc.coppe. ufrj.br/documentos/MCTI_PBMC_Sumario\%20Executivo\%204_ Finalizado.pdf. 22 Jun. 2020.

Pennington, R. T.; Lavin, M.; Oliveira-Filho, A. T. Woody plant diversity, evolution, and ecology in the tropics: perscpectives from seasonally dry tropical forests. Annual Review of Ecology, Evolution, and Systematics, v. 40, p. 437-457, 2009. https://doi. org/10.1146/annurev.ecolsys.110308.120327.

Phillips, S. J.; Anderson, R. P.; Schapire, R. E. Maximum entropy modeling of species geographic distributions. Ecological Modelling, v.190, n.3-4, p.231-259, 2006. https://doi. org/10.1016/j.ecolmodel.2005.03.026.

Salazar, L.; Nobre, C.; Oyama, M. Climate Change consenquences on the biome distribution in tropical South America. Geophysical Research Letters, v.34, n.9, L09708, 2007. https://doi. org/10.1029/2007GL029695.

Silva, J. L. S; Cruz-Neto O.; Peres, C. A.; Tabarelli, M.; Lopes, A. V. Climate change will reduce suitable Caatinga dry forest habitat for endemic plants with disproportionate impacts on specialized reproductive strategies. PLOS ONE, v.14, n.5, e0217028, 2019. https://doi.org/10.1371/journal.pone.0217028.
Silva, U. B. T.; Delgado-Jaramillo, M.; Aguiar, L. M. S.; Bernard, E. Species richness, geographic distribution, pressures, and threats to bats in the Caatinga drylands of Brazil. Biological Conservation, v.221, p. 312-322, 2018. https://doi.org/10.1016/j. biocon.2018.03.028.

Simões, S. S.; Zappi, D.; Costa, G. M.; Oliveira, G.; Aona, L.Y. S. Spatial nich modelling of five endemic cacti from the Brazilian Caatinga: Past, present and future. Austral Ecology, v. 45, n.1, p. 35-47, 2019. https://doi.org/10.1111/aec.12825,

Soberón, J.; Peterson, A. T. What is the shape of fundamental Grinnellian nich? Theoretical Ecology, v. 13, p. 105-115, 2020. https://doi.org/10.1007/s12080-019-0432-5.

Sobrinho, M. S.; Cavalcante, A. M. B.; Duarte, A. S.; Souza, G. S. Modeling the potential distribution of Mangifera indica $\mathrm{L}$. under future climate scenarios in the Caatinga Biome. Revista Brasileira de Meteorologia, v. 34, n.3, p. 351-358, 2019. https://doi. org/10.1590/0102-7786343052.

Swets, J. A. Measuring the accuracy of diagnostic systems. Science, v.240, n.4857, p.1285-1293, 1988. https://doi.org/10.1126/ science. 3287615 .

Vieira, F. A.; Novaes, R. M. L.; Fajardo, C. G.; Santos, R. M.; Almeida, H. S.; Carvalho, D.; Lovato, M. B. Holocene southward expansion in seasonally dry tropical forests in South America: phylogeography of Ficus bonijesulapensis (Moraceae). Botanical Journal of the Linnean Society, v. 177, n.2, p. 189-201, 2015. https://doi. org/10.1111/boj.12241,

Wei, J.; Zhang, H.; Zhao, W.; Zhao, Q. Niche shifts and the potential distribution of Phenacoccus solenopsis (Hemiptera: Pseudococcidae) under climate change. PLOS ONE, v. 12, n.7, e0180913, 2017. https://doi.org/10.1371/journal. pone.0180913.

Yang, A.; Gomez, J. P.; Blackburn, J. K. Exploring environmental coverages of species: a new variable contribution estimation methodology for rulesets from the genetic algorithm for ruleset prediction. PeerJ, v. 8, e8968, 2020. https://doi.org/10.7717/ peerj.8968. 